\title{
Hypofractionated Stereotactic Radiotherapy for Primary and Secondary Intrapulmonary Tumors
}

\author{
First Results of a Phase I/II Study
}

Antje Ernst-Stecken', Ulrike Lambrecht' ${ }^{1,2}$, Reinhold Mueller ${ }^{1,2}$, Rolf Sauer ${ }^{1}$, Gerhard Grabenbauer $^{1}$

\begin{abstract}
Purpose: To evaluate the feasibility, efficacy, and side effects of dose escalation in hypofractionated stereotactic radiotherapy (hfSRT) for intrapulmonary tumors with the Novalis ${ }^{\mathrm{TM}}$ system (BrainLAB AG, Heimstetten, Germany).

Patients and Methods: From 07/2003 to 01/2005, 21 patients/39 tumors were treated with $5 \times 7 \mathrm{~Gy}(\mathrm{n}=21$; total dose $35 \mathrm{~Gy})$ or $5 \times 8 \mathrm{~Gy}(\mathrm{n}=18$; total dose $40 \mathrm{~Gy})$. There were three cases of primary lung cancer, the remainder were metastases. Median gross tumor volume (GTV) and planning target volume (PTV) were $2.89 \mathrm{~cm}^{3}$ (range, $0.15-67.94 \mathrm{~cm}^{3}$ ) and $25.75 \mathrm{~cm}^{3}($ range, $\left.7.18-124.04 \mathrm{~cm}^{3}\right)$, respectively.

Results: Rates of complete remission, partial remission, no change, and progressive disease were $51 \%, 33 \%, 3 \%$, and $13 \%$, respectively. No grade 4 toxicity occurred, nearly all patients had grade 1 initially. One grade 3 toxicity, i.e., dyspnea, was documented for a period of 6 months after therapy. Radiosurgery quality assurance guidelines could be met.

Conclusion: hfSRT of primary and secondary lung tumors using a schedule of five fractions at 7-8 Gy each was well tolerated. Further dose escalation is planned.
\end{abstract}

Key Words: Hypofractionated stereotactic radiotherapy $\cdot$ Lung tumors $\cdot$ Novalis ${ }^{\mathrm{TM}}$ system

Strahlenther Onkol 2006;182:696-702

DOI $10.1007 / s 00066-006-1577-x$

\section{Hypofraktionierte stereotaktische Radiotherapie primärer und sekundärer Lungentumoren. Präliminäre Ergebnisse einer Phase-I/II-Studie}

Ziel: Auswertung der Durchführbarkeit, Wirksamkeit und Nebenwirkungen einer Phase-I/II-Studie zur Dosiseskalation bei hypofraktionierter stereotaktischer Radiotherapie (hfSRT) von Lungentumoren mit dem Novalis ${ }^{\mathrm{TM}}$-System (BrainLAB AG, Heimstetten).

Patienten und Methodik: 21 Patienten/39 Tumoren wurden von Juli 2003 bis Januar 2005 mit $5 \times 7$ Gy ( $n=21$; Gesamtdosis [GD] 35 Gy) oder $5 \times 8$ Gy ( $n=18$; GD 40 Gy) bestrahlt. Drei Patienten hatten ein primäres Lungenkarzinom, die übrigen Metastasen. Das mediane "gross tumor volume“ (GTV) und Planungszielvolumen (PTV) betrugen $2,89 \mathrm{~cm}^{3}\left(0,15-67,94 \mathrm{~cm}^{3}\right)$ und $25,75 \mathrm{~cm}^{3}$ $\left(7,18-124,04 \mathrm{~cm}^{3}\right)$.

Ergebnisse: Eine komplette Remission, partielle Remission, keine Änderung und Progression fanden sich bei 51\%, 33\%, 3\% und 13\%. Nach initialer Grad-1-Toxizität in fast allen Fälle trat keine Grad-4-Toxizität auf. Eine Patientin erlitt eine Grad-3-Toxizität. Die RTOG-Qualitätskriterien für die Radiochirurgie wurden bei allen Patienten erfüllt.

Schlussfolgerung: Die hfSRT mit $5 \times 7$ Gy und $5 \times 8$ Gy wurde gut vertragen. Die Dosiseskalation wird fortgeführt.

Schlüsselwörter: Hypofraktionierte stereotaktische Radiotherapie $\cdot$ Lungentumoren $\cdot$ Novalis ${ }^{\mathrm{TM}}$-System

\footnotetext{
${ }^{1}$ Department of Radiation Therapy and Novalis Shaped Beam Surgery Center, University Hospital Erlangen, Germany,

${ }^{2}$ Division of Medical Physics, Department of Radiation Therapy, University Hospital Erlangen, Germany.
}

Received: January 31, 2006; accepted: August 18, 2006 


\section{Introduction}

Stereotactic radiotherapy and radiosurgery (SRS) is well established for the treatment of brain tumors [5, 13, 15]. Given the ability to perform stereotactic radiosurgery and fractionated stereotactic treatment with the Novalis ${ }^{\mathrm{TM}}$ system (BrainLAB AG, Heimstetten, Germany), we decided to translate the technique into body stereotactic treatment. Extracranial stereotactic radiotherapy (ESRT) has demonstrated high efficacy and a low rate of side effects [4, 32, 36, 38]. Hypofractionation, from a radiobiological point of view, may yield significant benefits over using a single high-dose radiosurgery by opening up a therapeutic window between tumor control and late effects. This paradigm holds especially true for malignant tumors $[10,26]$. However, the optimal single and total dose have yet to be defined. In this paper, early results including toxicity of a phase I/II study of hypofractionated stereotactic radiotherapy (hfSRT) for intrapulmonary tumors are given.

\section{Patients and Methods}

\section{Eligibility and Process of Dose Escalation}

Treatment protocol and consent form were approved by an institutional review board and ethic's committee of the University of Erlangen, Germany. All patients were required to be medically inoperable or not eligible for surgery due to unfavorable tumor location as indicated by an experienced thoracic surgeon. Patients with stage I non-small cell lung cancer (NSCLC), i.e., T1 or T2 N0 M0, were accepted, if the gross tumor volume (GTV) had a diameter of $\leq 7 \mathrm{~cm}$ (existing data for hfSRT of lung cancer [31]). Second indication were patients with oligometastatic disease (up to four metastases, each of them not $>4 \mathrm{~cm}$, one single metastasis not $>7 \mathrm{~cm}$ in diameter). No exclusion criteria for FEV1 (forced expiratory volume in $1 \mathrm{~s}$ ) were defined, because hfSRT was the only alternative treatment to surgery. First dose level was $5 \times 7 \mathrm{~Gy}$ ( $90 \%$ isodose). Patient groups in the subsequent levels received an additional $1 \mathrm{~Gy}$ per fraction. Fractions were separated by an interval of 2 days. Overall treatment time was 10 days, including the weekend pause. A minimum of three patients should be assigned to each dose level. Toxicity was graded according to the Common Toxicity Criteria (CTC) [27]. Dose-limiting toxicity (DLT) was defined as any grade 3/4 pulmonary, esophageal, cardiac, or spinal toxicity. If two or more patients experienced DLT, the maximum tolerable dose (MTD) would be reached. If DLT occurred in one patient, another two for the same dose level would be enrolled. Proceeding to the next dose level without DLT in these two patients would be possible after a minimum observation period of 12 weeks after treatment.

\section{Patient and Tumor Characteristics}

21 patients were entered (07/2003-01/2005), median age 54 years (range, 18-75 years), Karnofsky performance status 80 (range, 70-100). Further characteristics are given in Table 1.
$\mathrm{FEV}_{1}<40 \%$ was present in three patients (one third required home oxygen therapy before hfSRT).

\section{Treatment Planning, Immobilization, and Radiation Delivery}

All patients were immobilized in supine position, with a self-constructed abdominal press with three plungers, one anterior and two on each flank (Figure 1). Helical CT images (3 mm, SomatomPlus4, Siemens, Erlangen, Germany) were obtained in deep inspiration breath hold (room lasers marked on the skin and three fiducial markers positioned). Solid tumor with blurred margin was considered to be GTV. Clinical target volume (CTV) was GTV without margin. Planning target volume (PTV), as to include setup inaccuracies and potential tumor movement, was the expansion of GTV plus 5,5 , and $10 \mathrm{~mm}$ in $\mathrm{x}-, \mathrm{y}-$, and $\mathrm{z}$-directions, respectively. Planning was performed with Novalis ${ }^{\mathrm{TM}}$ Brain Scan treatment-planning system (Version 5.31, BrainLAB AG). All isocenters were marked by the use of laser lines on the skin

Table 1. Patient and tumor characteristics. GTV: gross tumor volume; PTV: planning target volume.

Tabelle 1. Patienten- und Tumorcharakteristika. GTV: „gross tumor volume“; PTV: Planungszielvolumen.

Patients ( $n$ )

\begin{tabular}{lc}
\hline Age (years) & \\
Median & 54 \\
Range & $18-75$ \\
Gender & \\
Male & 8 \\
Female & 13 \\
Histology (39 tumors) & \\
Lung cancer & \\
- Adenocarcinoma & 8 \\
- Squamous cell carcinoma & 1 \\
Thyroid cancer & \\
- Follicular & 12 \\
Breast cancer & 4 \\
Rectal cancer & 8 \\
Cervical carcinoma & 2 \\
Ewing's sarcoma & 3 \\
Leiomyosarcoma & 1 \\
Tumor side & \\
Right lung & 18 \\
Left lung & 21 \\
Tumor location & \\
With $\leq 2 \mathrm{~cm}$ distance to basal pleura & 4 \\
With $\leq 2 \mathrm{~cm}$ distance to medial pleura & 13 \\
With $\leq 2 \mathrm{~cm}$ distance to lateral pleura & 14 \\
Central & 8 \\
Treatment volumes [cm ${ }^{3}$, median (range)] & \\
GTV & 2.89 (0.15-67.94) \\
PTV & 25.75 (7.18-124.04) \\
Dose level & \\
$5 \times 7$ Gy & 21 lesions \\
$5 \times 8$ Gy & 18 lesions \\
\end{tabular}


at our treatment simulation X-ray unit (Simulix-HQ, Nucletron, Veneridaal, The Netherlands). Radiation was delivered using a median number of three beams (range, one to six beams). In 38 cases, dynamic conformal arc technique was performed, in one case static conformal beams were used. Dose calculation was done by pencil beam algorithm. The treatment delivery Novalis ${ }^{\mathrm{TM}} /$ ExacTrac $^{\mathrm{TM}}$ system (BrainLAB $\mathrm{AG})$ has been described before [7]. ExacTrac ${ }^{\mathrm{TM}}$ is intended to

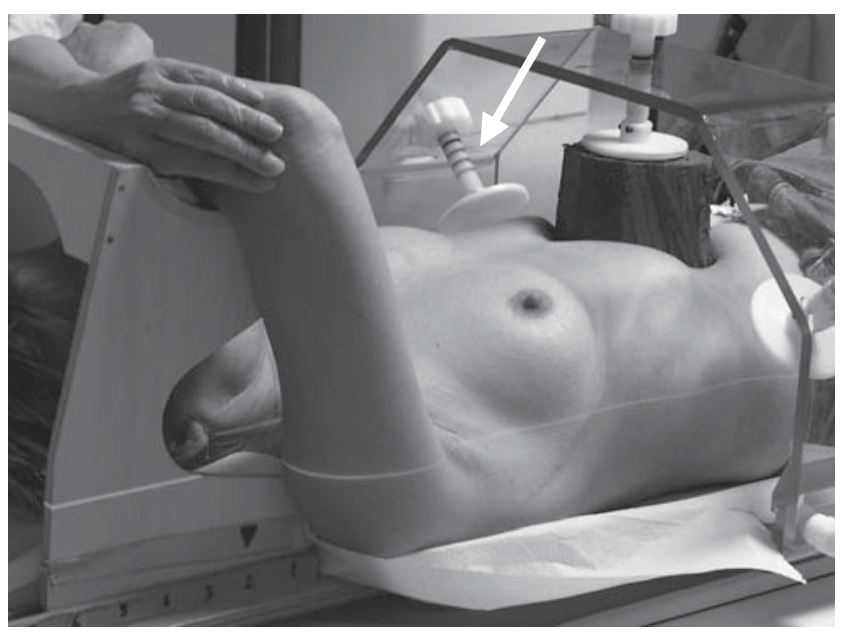

Figure 1a - Abbildung 1a

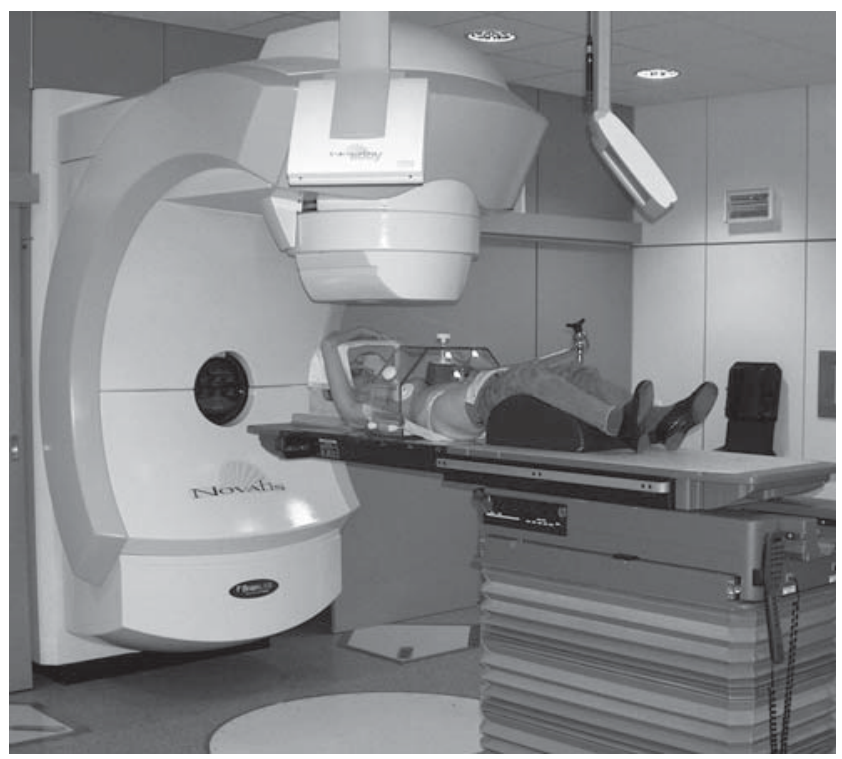

Figure $\mathbf{1 b}$ - Abbildung $\mathbf{1 b}$

Figures $\mathbf{1 a}$ and $\mathbf{1 b}$. Patient setup with abdominal press. Treatment planning with CT scan (a), setup at the linear accelerator (b). Arrow showing the individual and marked impression by the abdominal press.

Abbildungen 1a und $\mathbf{1 b}$. Patientenlagerung mit Bauchpresse. Lagerung bei der Computertomographie (a) und bei der Bestrahlung (b). Der Pfeil zeigt die individuell angepasste Imprimierung durch die Bauchpresse. place patients at the isocenter of a linear accelerator. It uses stereoscopic X-ray registration of two radiographs, X-ray fusion with the DRR (digitally reconstructed radiograph), and automatic positioning correction.

\section{Quality Criteria and Evaluation}

According to the RTOG guidelines [28] for radiosurgery dose homogeneity, conformation and $90 \%$ isodose coverage for $90 \%$ of the PTV were required. $\mathrm{D}_{\min }$ and $\mathrm{D}_{\max }$ were documented.

\section{Follow-up and Statistics}

We evaluated the quality of hfSRT using the aforementioned quality criteria and response after hfSRT with CT imaging 8 weeks after the end of hfSRT and every 3 months thereafter. Treatment-related side effects were documented according to the CTC scoring system.

\section{Results}

\section{Local Tumor Control and Survival}

Complete response (CR), partial response (PR), no change (NC), and progressive disease (PD) were seen in 51\%, 33\%, $3 \%$, and $13 \%$, respectively. This resulted in an overall response rate of $87 \%$ (no statistically significant difference between dose levels). Median follow-up was 6.3 months (range, 1-21 months). Four local relapses occurred after 8, 9 (two lesions), and 13 months. Eight patients (38\%) live with no evidence of disease, three are alive with progressive disease, six with new lung metastases, one with local control and extrapulmonary progressive disease, three died of local progressive disease (follow-up 1.4 months), extrapulmonary disease (follow-up 9 months) and other reasons (follow-up 2.3 months). Follow-up for patients without progression was 1-21 months (median 6.4 months). Local control was not associated with histology.

\section{Typical Follow-up Imaging Study}

The typical appearance of a treated tumor showing minimal change of normal lung tissue together with tumor shrinkage is demonstrated in Figure 2.

\section{Quality Criteria}

With the Novalis ${ }^{\mathrm{TM}}$ system, all of the RTOG quality criteria were met: median homogeneity index 1.16 (range, 1.02-1.36), median conformity index 1.29 (range, 1.12-1.98), and median coverage $97.8 \%$ (range, $86.6-100 \%$ ). Median maximum dose was $115 \%$ (range, 102-136\%), and medium minimum dose $88 \%$ (range, $70-100 \%$ ).

\section{Organs at Risk and Clinical Outcome}

Follow-up pulmonary function tests (PFTs) were only performed in the three patients with $\mathrm{FEV}_{1}<40 \%$. PFTs remained stable throughout the observation period. Grade 1 clinical side effects occurred in nearly all patients for up to 0.5 years, radiologic side effects for up to 1 year after treatment. No grade 

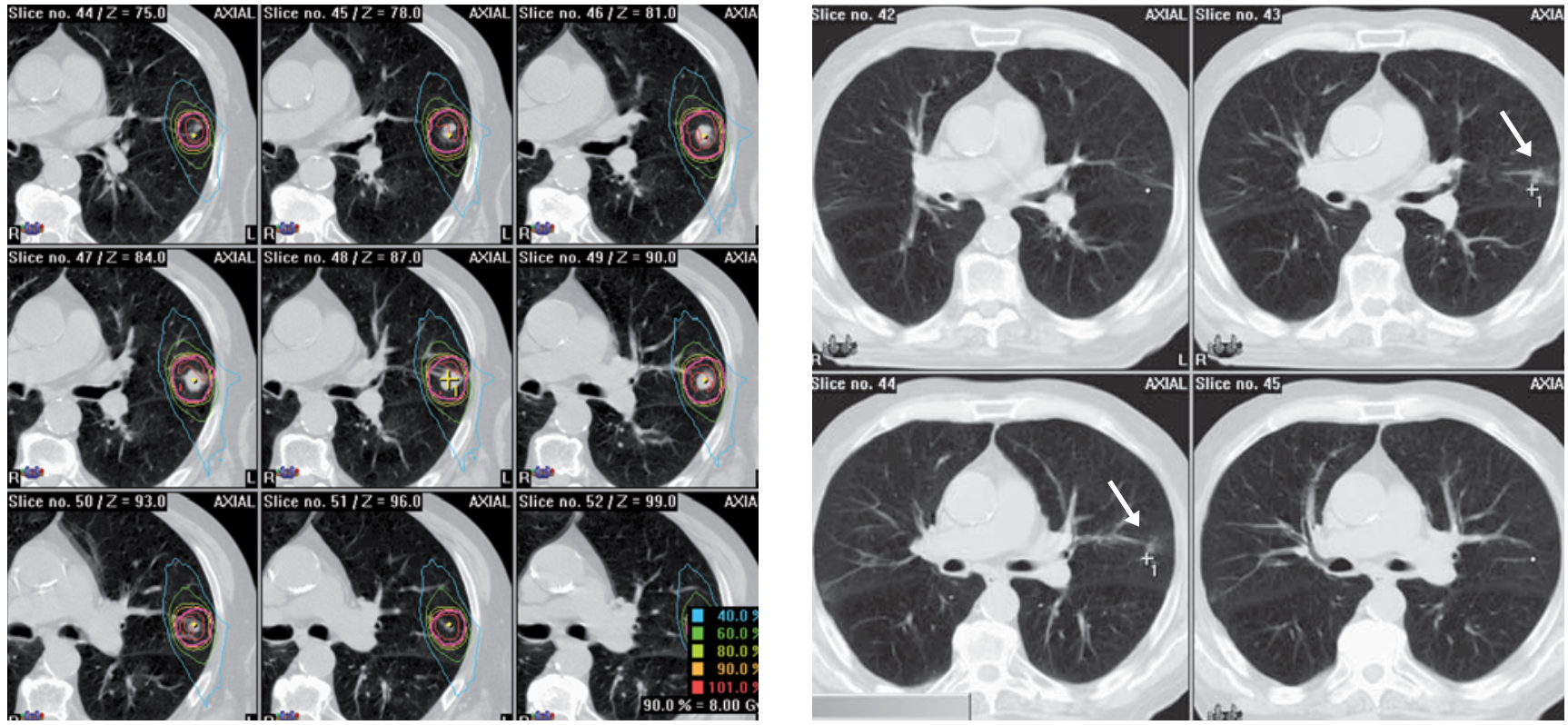

Figure 2a - Abbildung $2 a$

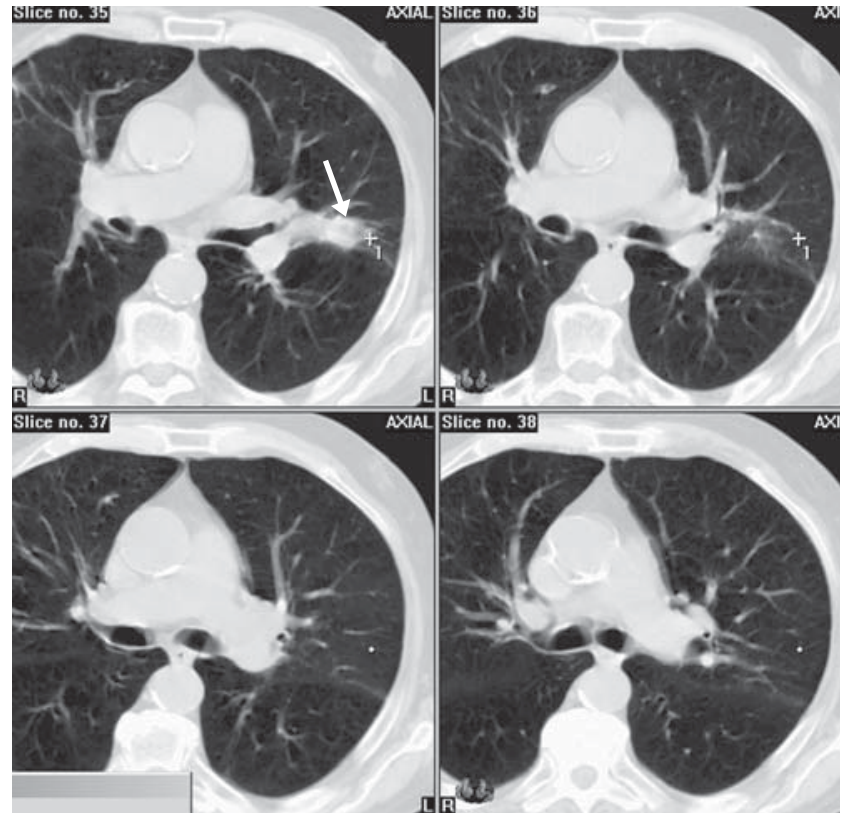

Figure 2c-Abbildung $2 c$

Figure $\mathbf{2 b}$ - Abbildung $\mathbf{2 b}$

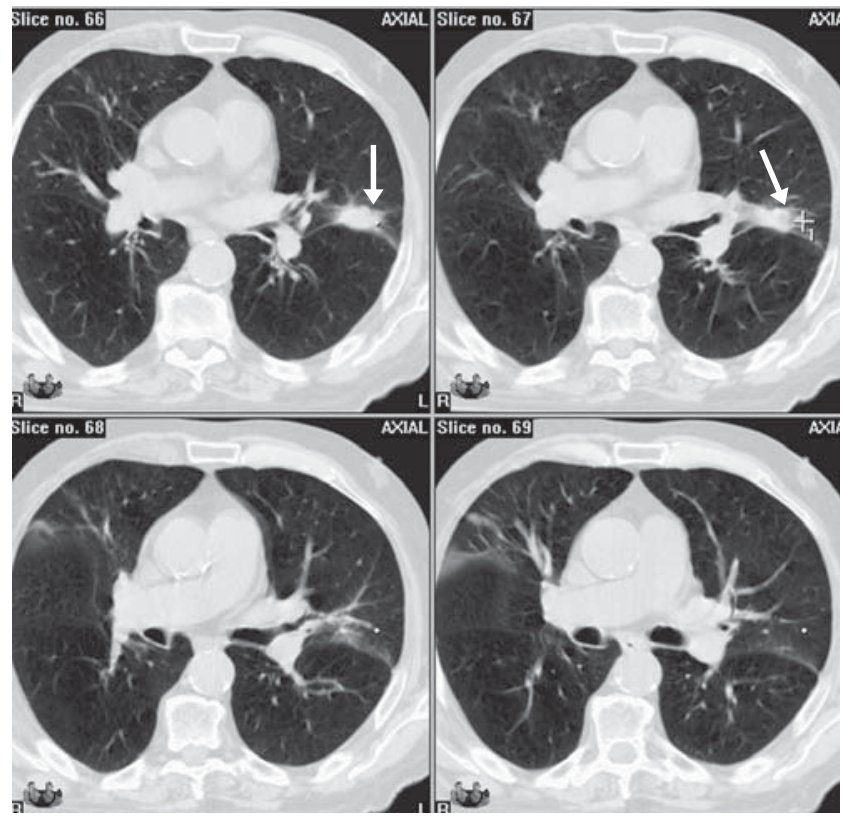

Figure 2d - Abbildung 2d

Figures 2 a to 2e. Case follow-up study. Treatment planning (a), three dynamic conformal arcs; follow-up at 6 months (b), 9 months (c), 12 months (d) and 15 months (e). Arrows showing the residual tumor (b) and the normal-tissue reactions (e) (continued next page).

Abbildungen 2a bis 2e. Fallbeispiel. Isodosenverläufe (a), drei dynamische Rotationen; Nachuntersuchung nach 6 Monaten (b), 9 Monaten (c), 12 Monaten (d) und 15 Monaten (e). Die Pfeile zeigen den Resttumor (b) und die Fibrose (e) (Fortsetzung s. nächste Seite).

2 pulmonary toxicity was seen. One patient (dose level 1) experienced grade 3 toxicity (dyspnea at rest, Table 2). This resolved with steroids after 0.5 years. Dose-volume histograms (DVHs) of normal lung tissue were documented. With 18 right-sided and 21 left-sided tumors, the following values were drawn from the DVHs: left lung: a median total volume of $180 \mathrm{~cm}^{3}$ (range, 0-730 $\mathrm{cm}^{3}$ ) was irradiated with $>2 \mathrm{~Gy}$, $77.5 \mathrm{~cm}^{3}$ (range, $0-250 \mathrm{~cm}^{3}$ ) with $>4 \mathrm{~Gy}$, and $42.5 \mathrm{~cm}^{3}$ (range, 0-140 $\mathrm{cm}^{3}$ ) with $>6 \mathrm{~Gy}$, respectively; right lung: a median total volume of $110 \mathrm{~cm}^{3}$ (range, $0-670 \mathrm{~cm}^{3}$ ) was irradiated with 


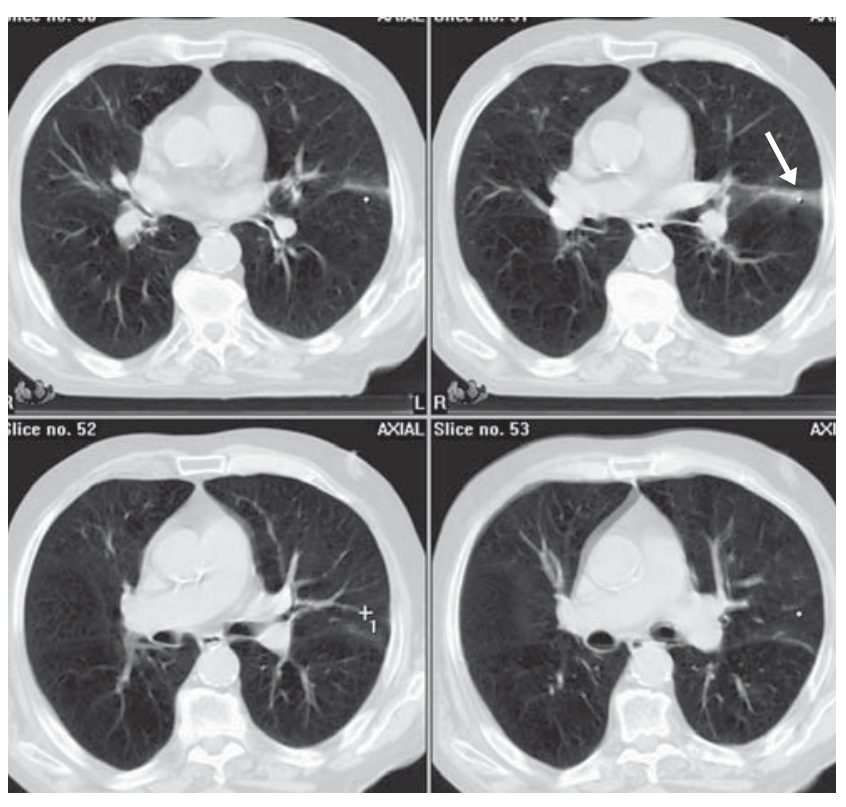

Figure 2e - Abbildung $2 e$

$>2 \mathrm{~Gy}, 30 \mathrm{~cm}^{3}$ (range, 0-305 $\mathrm{cm}^{3}$ ) with $>4 \mathrm{~Gy}$, and $20 \mathrm{~cm}^{3}$ (range, $0-180 \mathrm{~cm}^{3}$ ) with $>6 \mathrm{~Gy}$, respectively.

\section{Discussion \\ Rationale for Extracranial Stereotactic Radiotherapy (ESRT)}

Surgical resection remains the treatment of choice for patients with NSCLC stage I. However, there exists a large medically inoperable subgroup. Older studies revealed that $15 \%$ of these patients are long-term survivors, about $25 \%$ die of intercurrent disease, $30 \%$ of distant metastatic disease, and a significant percentage of $30 \%$ die after local failure only, respectively [29]. Regional failure only occurs in not more than about $7 \%$ of all stage I NSCLC patients [30]. Thus, elective node irradiation is not necessary. Patients with their primary controlled had a cause-specific survival at 5 years four times higher than those with uncontrolled primary $(46 \%$ vs. $12 \% ; \mathrm{p}=0.03)$ [30]. Retrospective data showed a trend toward improved cause-specific survival with higher radiotherapy doses. This emphasizes the need for dose-escalation studies. Belderbos et al. achieved nearly $90 \%$ overall response rate (CR and $\mathrm{PR})$ in 50 patients treated with a total dose of 74.3 or 81.0 Gy with 2.25 Gy per fraction. DLT was not reached at the last dose level [2]. However, until now, complete results of tox-
Figures $2 \mathbf{2}$ to $2 \mathbf{e}$ (continued). Case follow-up study. Follow-up at 15 months (e).

Abbildungen 2a bis $2 e$ (Fortsetzung). Fallbeispiel. Nachuntersuchung nach 15 Monaten (e).

icity except esophagitis have not been published yet [1]. SRS and hfSRT today have been expanded to extracranial targets $[3,22,33,36]$. Tumor control rates up to $85-97 \%$ have been reached which can compete with the best surgical series (Table 3) [21]. Systematic lymph node dissection in T1 and T2 tumors may no longer be essential due to staging with positron emission tomography. So, for the future, both modalities should be considered also with regard to low side effects after ESRT and low costs. Besides stage I NSCLC patients, a large proportion of our patient group were those with a finite number (one to four) of metastases (oligometastatic disease). From literature reviews, we know that these patients may experience improved survival by resection of their metastases and the primary site $[6,12]$.

Table 2. Toxicity (CTC [Common Toxicity Criteria] Score).

Tabelle 2. Toxizität (CTC-Score [Common Toxicity Criteria]).

\begin{tabular}{lrrrrrr}
\hline Follow-up time (months) & 2 & 5 & 8 & 11 & 14 & 17 \\
At risk & 39 & 32 & 13 & 11 & 8 & 8 \\
Grade 1 & 30 & 32 & 7 & 2 & 0 & 0 \\
Grade 2 & 0 & 0 & 0 & 0 & 0 & 0 \\
Grade 3 & 1 & 1 & 0 & 0 & 0 & 0 \\
Grade 4 & 0 & 0 & 0 & 0 & 0 & 0
\end{tabular}

Table 3. Review of literature. LC: local control; NSCLC: non-small cell lung cancer.

Tabelle 3. Literaturüberblick. LC: lokale Kontrolle; NSCLC: nichtkleinzelliges Bronchialkarzinom.

\begin{tabular}{|c|c|c|c|c|}
\hline Authors/year & Indications & $\begin{array}{l}\text { Dose concept } \\
\text { (dose specification) }\end{array}$ & $\begin{array}{l}\text { LC } \\
\text { (NSCLC) }\end{array}$ & $\begin{array}{l}\text { LC } \\
\text { (metastases) }\end{array}$ \\
\hline $\begin{array}{l}\text { Blomgren et al. } 1995 \\
\text { [3] }\end{array}$ & $\begin{array}{l}\text { Metastases } \\
\text { NSCLC }\end{array}$ & $\begin{array}{l}3 \times 10-2 \times 15 \mathrm{~Gy} \\
65 \% \text { isodose }\end{array}$ & $\begin{array}{l}3 / 3 \\
100 \%\end{array}$ & $\begin{array}{l}13 / 14 \\
93 \%\end{array}$ \\
\hline $\begin{array}{l}\text { Uematsu et al. } 1998 \\
\text { [33] }\end{array}$ & $\begin{array}{l}\text { Metastases } \\
\text { NSCLC }\end{array}$ & $\begin{array}{l}5-15 \mathrm{fx}, 30-76 \mathrm{~Gy} \\
80 \% \text { isodose }\end{array}$ & $\begin{array}{l}22 / 23 \\
96 \%\end{array}$ & $\begin{array}{l}42 / 43 \\
98 \%\end{array}$ \\
\hline $\begin{array}{l}\text { Uematsu et al. } 2001 \\
\text { [34] }\end{array}$ & NSCLC & $\begin{array}{l}5-10 \mathrm{fx}, 50-60 \mathrm{~Gy}, \\
100 \% \text { isodose, } \\
80 \% \text { coverage }\end{array}$ & $\begin{array}{l}47 / 50 \\
96 \%\end{array}$ & $\begin{array}{l}- \\
-\end{array}$ \\
\hline $\begin{array}{l}\text { Nagata et al. } 2002 \\
\text { [23] }\end{array}$ & $\begin{array}{l}\text { Metastases } \\
\text { NSCLC }\end{array}$ & $\begin{array}{l}4 \times 10-12 \mathrm{~Gy} \\
100 \% \text { isodose }\end{array}$ & $\begin{array}{l}31 / 33 \\
94 \%\end{array}$ & $\begin{array}{l}31 / 33 \\
94 \%\end{array}$ \\
\hline $\begin{array}{l}\text { Onimaru et al. } 2003 \\
\text { [25] }\end{array}$ & $\begin{array}{l}\text { Metastases } \\
\text { NSCLC }\end{array}$ & $\begin{array}{l}8 \mathrm{fx}, 40-60 \mathrm{~Gy}, \\
80-100 \% \text { isodose }\end{array}$ & $\begin{array}{l}20 / 25 \\
80 \%\end{array}$ & $\begin{array}{l}18 / 20 \\
90 \%\end{array}$ \\
\hline $\begin{array}{l}\text { Lee et al. } 2003 \\
\text { [20] }\end{array}$ & $\begin{array}{l}\text { Metastases } \\
\text { NSCLC }\end{array}$ & $\begin{array}{l}3-4 \times 10 \mathrm{~Gy} \\
90 \% \text { isodose }\end{array}$ & $\begin{array}{l}8 / 9 \\
89 \%\end{array}$ & $\begin{array}{l}23 / 25 \\
92 \%\end{array}$ \\
\hline $\begin{array}{l}\text { Timmerman et al. } 2003 \\
\text { [31] }\end{array}$ & NSCLC & $\begin{array}{l}3 \times 8-3 \times 20 \mathrm{~Gy} \\
80 \% \text { isodose }\end{array}$ & $\begin{array}{l}31 / 37 \\
84 \% \\
\text { no relapse } \geq 18 \text { Gy }\end{array}$ & \\
\hline This study & NSCLC & $\begin{array}{l}5 \times 7-8 \mathrm{~Gy} \\
90 \% \text { isodose }\end{array}$ & $\begin{array}{l}3 / 3 \\
100 \%\end{array}$ & $\begin{array}{l}31 / 36 \\
86 \%\end{array}$ \\
\hline
\end{tabular}




\section{Patient Setup Accuracy}

The following prerequisites have to be met for high setup accuracy: reliable immobilization, reduction of organ motion, and quick radiation delivery. Different fixation methods for patients are used. A system using a stereotactic body frame with integrated vacuum pillow revealed positioning errors in all directions of up to $5 \mathrm{~mm}$ and target setup deviations of up to $10 \mathrm{~mm}[14,19,24]$. Since the Novalis ${ }^{\mathrm{TM}}$ system allows for the control of deviations as related to bony structures in all six planes, i.e., translational and rotational directions, there is no necessity of correctly positioning a frame around the patient as the bony landmarks themselves are positioned. X-ray verification with ExacTrac ${ }^{\mathrm{TM}}$ revealed a setup accuracy within $1 \mathrm{~mm}$ in all directions for all patients. In addition, abdominal pressure devices may significantly reduce organ movements $[14,19,33]$. Therefore, a home-built abdominal press was implemented into our system (Figure 1). We applied as much pressure as could be tolerated without any side effects. However, even with abdominal pressure, breathing mobility remains the major factor for setup inaccuracy, especially for lesions close to the diaphragm [16].

\section{Dose Prescription, Planning Algorithm, and Radiation Dose Delivery}

According to literature data, using SRS techniques, lung tumors are being treated with two to eight fractions of 5-20 Gy each. Although overall response rates varied in an only small range between $80 \%$ and $100 \%$ [3, 20, 23, 25, 31, 33], a comparison of the results remains difficult because of different total dose and variations in dose prescription. According to the existing data, dose was being prescribed to the $65-100 \%$ isodose and there is no evidence, that an increased inhomogeneity inside the target volume may be followed by higher response rates (Table 3). As an admission to the guidelines for cranial radiosurgery, we would recommend to meet the requirements for homogeneity, coverage and conformity [28] in order to better compare the future results.

Another problem is the lack of detailed information on the calculation models that are used. It is well known for low-density lung tissue, that simple calculation models like pencil beam algorithm in contrast to collapsed cone and Monte Carlo algorithm may overestimate the amount of absorbed dose up to $20 \%$ at the interface between tumor and lung tissue. Several studies have proven this effect especially for prescription of the dose to the edge of the target, for small targets with a PTV $\leq 100 \mathrm{~cm}^{3}$ and the use of high-energy, i.e., $18-\mathrm{MeV}$, photons $[9,17,18]$ as compared to low-energy photons. Consequently, the more reliable collapsed cone algorithm should be used in future trials.

The majority of our patients were treated by dynamic conformal arcs guaranteeing a maximum of dose conformity. Furthermore, it is reasonable to disperse the dose outside the target volume over large areas and reduce the lung volumes receiving high doses. Willner et al. [35] showed that reducing the high-dose volume will result in a lower pneumonitis rate as compared to a reduction of lung volumes receiving low dose.

\section{Response Rates and Toxicity}

Until now, a number of well-conducted studies revealed remarkably good results following fractionated stereotactic treatment of early lung cancer (Table 3). Few data, however, exist on toxicity after hfSRT of lung tumors: acute grade 1 toxicity was documented in 5-9\% of patients [33], and grade 2 toxicity in $4 \%$ of patients $[11,25]$, respectively. Severe side effects were only reported occasionally $[3,25]$. Our data compare very favorably with these results. Nevertheless, four patients relapsed in this series up to 13 months after treatment, even after $5 \times 8$ Gy. Timmerman et al. [31] saw no recurrences when treating patients with doses $>3 \times 18 \mathrm{~Gy}$. Using the simple calculation model given by Fowler [8] assuming an $\alpha / \beta$-value of $10 \mathrm{~Gy}$ for malignant tumors, the two aforementioned schedules translate into an equivalent total dose of $126 \mathrm{~Gy}_{2}$ and $60 \mathrm{~Gy}_{2}$, respectively. An escalation to $5 \times 9 \mathrm{~Gy}$ would gain another 11.25 Gy. Using another model described by Yaes \& Maruyama [37], keeping the same $\alpha / \beta$-value of $10 \mathrm{~Gy}$, the biologically effective doses of $151.2 \mathrm{~Gy}_{2}$ versus $72 \mathrm{~Gy}_{2}$ would result, respectively.

\section{Conclusion}

hfSRT of lung tumors using a dose-escalating schedule of five fractions with 7 Gy and 8 Gy was well tolerated. Dose escalation will be continued.

\section{References}

1. Belderbos J, Heemsbergen W, Hoogeman M, et al. Acute esophageal toxicity in non-small cell lung cancer patients after high-dose conformal radiotherapy. Radiother Oncol 2005;75:157-64.

2. Belderbos JS, De Jaeger K, Heemsbergen WD, et al. First results of a phase $\mathrm{I} / \mathrm{II}$ dose escalation trial in non-small cell lung cancer using three-dimensional conformal radiotherapy. Radiother Oncol 2003;66:119-26.

3. Blomgren H, Lax I, Naslund I, et al. Stereotactic high-dose fraction radiation therapy of extracranial tumors using an accelerator. Clinical experience of the first thirty-one patients. Acta Oncol 1995;34:861-70.

4. Boda-Heggemann J, Walter C, Mai S, et al. Frameless stereotactic radiosurgery of a solitary liver metastasis using active breathing control and stereotactic ultrasound. Strahlenther Onkol 2006;182:216-21.

5. Combs SE, Gutwein S, Thilmann C, et al. Reirradiation of recurrent WHO grade III astrocytomas using fractionated stereotactic radiotherapy (FSRT). Strahlenther Onkol 2005;181:768-73.

6. Downey $\mathrm{RJ}, \mathrm{Ng} \mathrm{K}$. The management of non-small-cell lung cancer with oligometastases. Chest Surg Clin N Am 2001;11:121-32.

7. Ernst-Stecken A, Lambrecht U, Ganslandt 0, et al. Radiosurgery of small skull-base lesions. No advantage for intensity-modulated stereotactic radiosurgery versus conformal arc technique. Strahlenther Onkol 2005; 181:336-44.

8. Fowler J. Non-standard fractionation in radiotherapy. Int J Radiat Oncol Biol Phys 1984;10:755-9.

9. Haedinger $U$, Flentje $M$, Wulf J, et al. Influence of calculation model on dose distribution in stereotactic radiotherapy for pulmonary targets. Int $\mathrm{J}$ Radiat Oncol Biol Phys 2005;61:239-49.

10. Hall EJ, Brenner D. The radiobiology of radiosurgery: rationale for different treatment regimes for AVMs and malignancies. Int J Radiat Oncol Biol Phys 1993;25:381-5. 
11. Hara R, Kondo T, Aruga T, et al. Stereotactic single high dose irradiation of lung tumors under respiratory gating. Radiother Oncol 2002;63:159-63.

12. Hellman S, Weichselbaum R. Oligometastases. J Clin Oncol 1995;13:8-10.

13. Henzel M, Gross M, Hamm K, et al. Stereotactic radiotherapy of meningiomas. Symptomatology, acute and late toxicity. Strahlenther Onkol 2006; 182:382-8

14. Herfarth KK, Lohr F, Bahner ML, et al. Extracranial stereotactic radiation therapy: set-up accuracy of patients treated for liver metastases. Int J Radiat Oncol Biol Phys 2000;46:329-35.

15. Hocht S, Stark R, Seiler F, et al. Proton or stereotactic photon irradiation for posterior uveal melanoma? A planning intercomparison. Strahlenther Onkol 2005;181:783-8.

16. Hof $H$, Munter $M$, Hoess $A$, et al. Stereotactic single-dose radiotherapy of stage I non-small-cell lung cancer (NSCLC). Int J Radiat Oncol Biol Phys 2003;56:335-41.

17. Koelbl 0 , Haedinger $U$, Sauer 0 , et al. Influence of calculation algorithm on dose distribution in irradiation of non-small cell lung cancer (NSCLC). Collapsed cone versus pencil beam. Strahlenther Onkol 2004;180:783-8.

18. Krieger T. Monte Carlo- versus pencil-beam-/collapsed-cone-dose calculation in a heterogeneous multi-layer phantom. Phys Med Biol 2005;50:859-68.

19. Lax I, Blomgren H, Naslund I, et al. Stereotactic radiotherapy of malignancies in the abdomen. Methodological aspects. Acta Oncol 1994;33:677-83.

20. Lee SW, Park HJ, Ahn SD, et al. Stereotactic body frame based fractionated radiosurgery on consecutive days for primary or metastatic tumors in the lung. Lung Cancer 2003;40:309-15.

21. Martini N, Burt M, Zakowski MF, et al. Incidence of local recurrence and second primary tumors in resected stage I lung cancer. J Thorac Cardiovasc Surg 1995;109:120-9.

22. Munter MW, Nill S, Thilmann C, et al. Stereotactic intensity-modulated radiation therapy (IMRT) and inverse treatment planning for advanced pleural mesothelioma. Feasibility and initial results. Strahlenther Onkol 2003; 179:535-41.

23. Nagata Y, Aoki T, Mizowaki T, et al. Clinical outcomes of 3D conformal hypofractionated single high-dose radiotherapy for one or two lung tumors using a stereotactic body frame. Int J Radiat Oncol Biol Phys 2002;52:1041-6.

24. Nevinny-Stickel M, Sweeney R, Bale RJ. Reproducibility of patient positioning for fractionated extracranial stereotactic radiotherapy using a double-vacuum technique. Strahlenther Onkol 2004;180:117-22.

25. Onimaru R, Shimizu S, Kitamura K, et al. Tolerance of organs at risk in small-volume, hypofractionated, image-guided radiotherapy for primary and metastatic lung cancers. Int J Radiat Oncol Biol Phys 2003;56:126-35.

26. Ruggieri L. Hypofractionation in non-small cell lung cancer (NSCLC): suggestions from modelling both acute and chronic hypoxia. Phys Med Biol 2004;49:4811-23.

27. Seegenschmiedt MH. Interdisciplinary documentation of treatment side effects in oncology. Present status and perspectives. Strahlenther Onkol 1998;174:Suppl 3:25-9.
28. Shaw E, Gillin M, Souhami L, et al. Radiation Therapy Oncology Group: radiosurgery quality assurance guidelines. Int J Radiat Oncol Biol Phys 1993; 27:1231-9.

29. Sibley GS. Radiotherapy for patients with medically inoperable stage I nonsmall cell lung carcinoma: smaller volumes and higher doses - a review. Cancer 1998;82:433-8.

30. Sibley GS, Jamieson T, Marks LB, et al. Radiotherapy alone for medically inoperable stage I non-small-cell lung cancer: the Duke experience. Int J Radiat Oncol Biol Phys 1998;40:149-54.

31. Timmerman R, Papiez L, McGarry R, et al. Extracranial stereotactic radioablation: results of a phase I study in medically inoperable stage I non-small cell lung cancer. Chest 2003;124:1946-55.

32. Timmerman R, Papiez L, Suntharalingam M. Extracranial stereotactic radiation delivery: expansion of technology beyond the brain. Technol Cancer Res Treat 2003;2:153-60.

33. Uematsu M, Shioda A, Tahara K, et al. Focal, high dose, and fractionated modified stereotactic radiation therapy for lung carcinoma patients: a preliminary experience. Cancer 1998;82:1062-70.

34. Uematsu M, Shioda A, Suda A, et al. Computed tomography-guided stereotactic radiotherapy for stage I non-small cell lung cancer: a 5-year experience. Int J Radiat Oncol Biol Phys 2001;51:666-70.

35. Willner J, Baier K, Flentje M. A little to a lot or a lot to a little? An analysis of pneumonitis risk from dose-volume histogram parameters of the lung in patients with lung cancer treated with 3-D conformal radiotherapy. Strahlenther Onkol 2003;179:548-56.

36. Wulf J, Haedinger U, Oppitz U, et al. Stereotactic radiotherapy of targets in the lung and liver. Strahlenther Onkol 2001;177:645-55.

37. Yaes RJ, Maruyama Y. On using the linear-quadratic model in daily clinical practice. Int J Radiat Oncol Biol Phys 1991;20:1353-62.

38. Zimmermann FB, Geinitz H, Schill S, et al. Stereotactic hypofractionated radiation therapy for stage I non-small cell lung cancer. Lung Cancer 2005; 48:107-14.

Address for Correspondence

Dr. Antje Ernst-Stecken

Strahlentherapeutische Universitätsklinik

Universitätsstraße 27

91054 Erlangen

Germany

Phone (+49/9131) 85-3405, Fax -9335

e-mail: antje.ernst-stecken@strahlen.imed.uni-erlangen.de 